\title{
Eco-friendly management of anthracnose of chilli caused by Colletotrichum capsici
}

\author{
Salma Begum* and P. S. Nath \\ Department of Plant Pathology, Bidhan Chandra Krishi Viswavidyalaya, Mohanpur, Nadia- 741252 (West Bengal), \\ INDIA \\ *Corresponding author: E-mail: salmabegumsalmabegum@gmail.com \\ Received: November 14, 2014; Revised received: March 3, 2015; Accepted: March 16, 2015
}

\begin{abstract}
The anthracnose of chilli caused by Colletotrichum capsici is a wide spread problem limiting the profitable cultivation and seed production of chilli throughout the major chilli growing regions of India. Four isolates $\left(\mathrm{SCC}_{1}\right.$, $\mathrm{SCC}_{2}, \mathrm{SCC}_{3}$ and $\mathrm{SCC}_{4}$ ) of C. capsici were collected from different chilli growing areas of West Bengal. An experiment on efficacy of four botanical oils viz., Garlic (Allium sativum), Neem (Azadirachta indica), Polyalthia (Polyalthia longifolia) and Citronella(Cymbopogon nardus) at concentrations of $0.05 \%, 0.1 \%$ and $0.2 \%$ and two isolates each of three biocontrol agents (Trichoderma harzianum, T. viride and Pseudomonas flourescens) were carried out against these isolates of C. capsici in vitro. The result revealed significant (5\% level of significance) antifungal activities of these botanicals and biocontrol agents. Garlic gave cent per cent inhibition of mycelial growth of all the four isolates of C. capsici at all the concentrations tested. However, neem showed cent per cent inhibition of mycelial growth of $C$. capsici at $0.1 \%$. Citronella was least effective among the botanical oils. Among the biocontrol agents tested T. harzianum isolate Th-2 was found most effective giving $77.78 \%, 100 \%, 83.33 \%$ and $88.89 \%$ inhibition on the mycelial growth of $\mathrm{SCC}_{1}, \mathrm{SCC}_{2}, \mathrm{SCC}_{3}$ and $\mathrm{SCC}_{4}$ respectively followed by $\mathrm{T}$. harzianum isolate Th-1 inhibiting $74.00 \%, 78.9 \% 81.7 \%$ and $80.90 \%$ of the mycelial growth of $\mathrm{SCC}_{1}, \mathrm{SCC}_{2}, \mathrm{SCC}_{3}$ and $\mathrm{SCC}_{4}$ respectively. $P$. fluorescens was least effective. Thus, garlic, neem, polyalthia, T. harzianum and T. viride can be utilized for management of anthracnose of chilli.
\end{abstract}

Keywords: Anthracnose, Biocontrol Agents, Botanical Oils, Colletotrichum capsici, Isolates

\section{INTRODUCTION}

India accounts for $25 \%$ of the world's total production of chilli. The crop is a significant source of income making in India, the world's single largest producer and exporter to the USA, Canada, UK, Saudi Arabia, Singapore, Malaysia, Germany and many other countries across the world (Ashwini and Srividya, 2014). The sustainability of chilli-based agriculture is threatened by a number of factors. Anthracnose disease is a major problem in India and one of the most significant economic constraints to chilli production worldwide, especially in tropical and subtropical regions (Than et al., 2008). Economic losses caused by the disease are mainly attributed to lower fruit quality and marketability. The control of chilli anthracnose fruit rot has, for many years, relied on chemicals and resulted in many undesirable problems. There are numerous reports of negative effects of using chemicals on farmers' income and health, and toxic contamination to the environment, particularly in developing countries (Voorrips et al., 2004). Thus, there is a need to incorporate alternative control components that are effective in field. The use of botanical oils and biocontrol agents is the best alternative for management of chilli anthracnose. There is little work done on exploitation of botanicals and biocontrol agents. As chilli is an edible crop and large quantity of pesticides are being used, there is growing demand for chemical pesticide free organic chilli world over. Hence, the present investigation was undertaken to find the eco-friendly management of anthracnose of chilli caused by Colletotrichum capsici.

\section{MATERIALS AND METHODS}

The present investigation was conducted in the laboratory of the Department of Plant Pathology, Faculty of Agriculture, Bidhan Chandra Krishi Viswavidyalaya, Mohanpur, West Bengal during 2013-14.

Collection, isolation and identification of $C$. capsici: Chilli fruits showing typical fruit rot symptoms include sunken necrotic tissues, with concentric rings of acervuli were collected from different localities of West Bengal. Infected fruit bits were surface sterilized in $0.1 \%$ mercuric chloride for 30 seconds and repeatedly washed with sterilized distilled water to remove traces of mercury and then transferred to water agar media and incubated at $27 \pm 1^{\circ} \mathrm{C}$. Fungal mycelium developed from the infected tissue in water agar media was finally transferred to Potato Dextrose Agar (PDA) slants and incubated at $27 \pm 1^{\circ} \mathrm{C}$ to obtain pure culture of $C$. capsici. Four isolates of the fungus were collected from different areas of West Bengal. Identification of the fungus was done with microscope. 
In vitro effect of botanical oils: Four botanical oils viz., Garlic (Allium sativum), Neem (Azadirachta indica), Polyalthia (Polyalthia longifolia) and Citronella (Cymbopogon nardus) were tested for their efficacy against four isolates $\left(\mathrm{SCC}_{1}, \mathrm{SCC}_{2}, \mathrm{SCC}_{3}\right.$ and $\left.\mathrm{SCC}_{4}\right)$ of
C. capsici of at concentrations $0.05 \%, 0.1 \%$ and $0.2 \%$. The poisoned food technique (Shervelle, 1979) was followed to evaluate the efficacy of essential oils in laboratory against the test fungus. Required amount of oil extracts were dissolved in 5\% tween 80 (5g of

Table 1. In vitro efficacy of botanical oils on the mycelial growth of C. capsici.

\begin{tabular}{|c|c|c|c|c|}
\hline \multirow[t]{3}{*}{ Botanical oil } & \multicolumn{4}{|c|}{$\%$ inhibition of mycelial growth } \\
\hline & \multicolumn{4}{|c|}{ Concentration } \\
\hline & $0.05 \%$ & $0.10 \%$ & & $0.20 \%$ \\
\hline \multicolumn{5}{|l|}{ Isolate $\mathrm{SCC}_{1}$} \\
\hline Garlic & $100(90.00)$ & $100(90.00)$ & & $100(90.00)$ \\
\hline Neem & $84.45(66.78)$ & $100(90.00)$ & & $100(90.00)$ \\
\hline Polyalthia & $73.89(59.27)$ & $78.89(62.65)$ & & $84.45(66.78)$ \\
\hline Citronella & $8.27(16.71)$ & $8.36(16.81)$ & & $13.84(21.84)$ \\
\hline \multirow[t]{2}{*}{ Solvent } & $7.80(16.22)$ & $8.00(16.43)$ & & $8.14(16.58)$ \\
\hline & Botanical oil ( B ) & Concentration ( C ) & & $\mathrm{B} \times \mathrm{C}$ \\
\hline $\mathrm{CD}$ at $5 \%$ & 0.62 & 0.48 & & 1.08 \\
\hline $\operatorname{SEm} \pm$ & 0.21 & 0.17 & & 0.37 \\
\hline \multicolumn{5}{|l|}{ Isolate $\mathrm{SCC}_{2}$} \\
\hline Garlic & $100(90.00)$ & $100(90.00)$ & & $100(90.00)$ \\
\hline Neem & $82.78(65.48)$ & $100(90.00)$ & & $100(90.00)$ \\
\hline Polyalthia & $58.34(49.80)$ & $76.67(61.12)$ & & $85.00(67.21)$ \\
\hline Citronella & $8.29(16.73)$ & $8.44(16.89)$ & & $13.7621 .77)$ \\
\hline \multirow[t]{2}{*}{ Solvent } & $7.80(16.22)$ & $8.00(16.43)$ & & $8.14(16.58)$ \\
\hline & Botanical oil ( B ) & Concentration ( C ) & & $\mathrm{B} \times \mathrm{C}$ \\
\hline $\mathrm{CD}$ at $5 \%$ & 0.58 & 0.45 & & 1.00 \\
\hline $\mathrm{SEm} \pm$ & 0.20 & 0.16 & & 0.35 \\
\hline \multicolumn{5}{|l|}{ Isolate $\mathrm{SCC}_{3}$} \\
\hline Garlic & $100(90.00)$ & $100(90.00)$ & & $100(90.00)$ \\
\hline Neem & $82.22(65.06)$ & $100(90.00)$ & & $100(90.00)$ \\
\hline Polyalthia & $75.00(60.00)$ & $86.11(68.12)$ & & $100(90)$ \\
\hline Citronella & $8.30(16.74)$ & 8.44 (16.89) & & $12.31(20.54)$ \\
\hline \multirow[t]{2}{*}{ Solvent } & $7.80(16.22)$ & $8.00(16.43)$ & & $8.14(16.58)$ \\
\hline & Botanical oil ( B ) & Concentration ( C ) & & $\mathrm{B} \times \mathrm{C}$ \\
\hline $\mathrm{CD}$ at $5 \%$ & 0.56 & 0.43 & & 0.96 \\
\hline $\mathrm{SEm} \pm$ & 0.19 & 0.15 & & 0.33 \\
\hline \multicolumn{5}{|l|}{ Isolate $\mathrm{SCC}_{4}$} \\
\hline Garlic & $100(90.00)$ & $100(90.00)$ & & $100(90.00)$ \\
\hline Neem & $83.33(65.90)$ & $100(90.00)$ & & $100(90.00)$ \\
\hline Polyalthia & $62.22(52.07)$ & $80.00(63.43)$ & & $85.00(67.21)$ \\
\hline Citronella & 8.23 (16.67) & 8.33 (16.67) & & $10.23(18.65)$ \\
\hline \multirow[t]{2}{*}{ Solvent } & $7.80(16.22)$ & $8.00(16.43)$ & & $8.14(16.58)$ \\
\hline & Botanical oil ( B ) & Concentration ( C ) & & $\mathrm{B} \times \mathrm{C}$ \\
\hline $\mathrm{CD}$ at $5 \%$ & 0.60 & & 0.46 & 1.04 \\
\hline $\mathrm{SEm} \pm$ & 0.21 & & 0.16 & 0.36 \\
\hline
\end{tabular}

\footnotetext{
* Figures in parenthesis are arcsine transformed values.
} 
Table 2. In vitro efficacy of biocontrol agents on the mycelial growth of C. capsici.

\begin{tabular}{|c|c|c|}
\hline Biocontrol agents & Isolate & Per cent inhibition of mycelial growth \\
\hline \multicolumn{3}{|l|}{ Isolate $\mathrm{SCC}_{1}$} \\
\hline T. harzianum & Th-1 & $74.00(59.34)$ \\
\hline T. harzianum & Th-2 & $77.78(61.88)$ \\
\hline T. viride & TV-1 & $73.90(59.28)$ \\
\hline T. viride & Tv-2 & $72.22(58.19)$ \\
\hline P. fluorescence & Ps-1 & $31.44(34.11)$ \\
\hline P. fluorescence & Ps-2 & $50.00(45.00)$ \\
\hline Control & & $0(0.00)$ \\
\hline $\mathrm{CD}$ at $5 \%$ & & 1.88 \\
\hline $\operatorname{S.Em} \pm$ & & 0.62 \\
\hline \multicolumn{3}{|l|}{ Isolate $\mathrm{SCC}_{2}$} \\
\hline T. harzianum & Th-1 & $78.90(62.65)$ \\
\hline T. harzianum & Th-2 & $100(90.00)$ \\
\hline T. viride & Tv-1 & $72.90(58.63)$ \\
\hline T. viride & Tv-2 & $66.67(54.74)$ \\
\hline P. fluorescence & Ps-1 & $29.67(33.00)$ \\
\hline P. fluorescence & Ps-2 & $44.44(41.81)$ \\
\hline Control & & $0(0.00)$ \\
\hline $\mathrm{CD}$ at $5 \%$ & & 1.65 \\
\hline S.Em \pm & & 0.54 \\
\hline \multicolumn{3}{|l|}{ Isolate $\mathrm{SCC}_{3}$} \\
\hline T. harzianum & Th-1 & $81.70(64.67)$ \\
\hline T. harzianum & Th-2 & $83.33(65.90)$ \\
\hline T. viride & Tv-1 & $75.40(60.27)$ \\
\hline T. viride & Tv-2 & $77.7861 .88)$ \\
\hline P. fluorescence & Ps-1 & $16.67(24.10)$ \\
\hline P. fluorescence & Ps-2 & $42.22(40.52)$ \\
\hline Control & & $0(0.00)$ \\
\hline $\mathrm{CD}$ at $5 \%$ & & 2.18 \\
\hline S.Em \pm & & 0.72 \\
\hline \multicolumn{3}{|l|}{ Isolate $\mathrm{SCC}_{4}$} \\
\hline T. harzianum & Th-1 & $80.90(60.09)$ \\
\hline T. harzianum & Th-2 & $88.8970 .53)$ \\
\hline T. viride & TV-1 & $76.20(60.80)$ \\
\hline T. viride & Tv-2 & $72.22(58.19)$ \\
\hline P. fluorescence & Ps-1 & $22.22(28.12)$ \\
\hline P. fluorescence & Ps-2 & $38.89(38.58)$ \\
\hline Control & & $0(0.00)$ \\
\hline $\mathrm{CD}$ at $5 \%$ & & 2.15 \\
\hline S.Em \pm & & 0.71 \\
\hline
\end{tabular}

* Figures in parenthesis are arcsine transformed values.

tween $80+95 \mathrm{~g}$ of xylene) and thoroughly mixed with melted PDA to provide concentrations of $0.05,0.1$ and
$0.2 \%$ with three replications each of different botanical oils. The actively growing periphery of seven days old 
culture of $C$. capsici was aseptically transferred to the centre of each petri plates containing the poisoned solid media. Suitable control was maintained by growing the cultures on PDA without botanical oils. Inoculated plates were incubated at $27 \pm 1^{\circ} \mathrm{C}$ for twelve days and colony diameter was recorded. Per cent inhibition of growth of the test fungus was calculated by using the formula of Vincent (1947) as given below:

$$
\mathrm{I}=\frac{C-T}{C} \times 100
$$

Where, $\mathrm{I}=$ per cent inhibition; $\mathrm{C}=$ linear growth of the fungus in control $(\mathrm{cm})$ and $\mathrm{T}=$ linear growth of the fungus in treatment $(\mathrm{cm})$

In vitro effect of biocontrol agents : Two isolates each of three bioagents viz., Trichoderma harzianum, T. viride and Pseudomonas fluorescens were evaluated for their antagonistic properties against C. capsici through dual culture technique (Faheem et al., 2010). The bioagents and the test fungus were inoculated side by side on a single petridish containing solidified PDA medium. Three replications were maintained for each treatment with one control by maintaining only pathogen and bioagent separately. Inoculated plates were incubated at $27 \pm 1^{\circ} \mathrm{C}$ for twelve days. The diameter of the colony of both bioagents and the pathogen was measured in two directions and average was recorded. Per cent inhibition of growth of the test fungus was calculated by using the formula of Vincent (1947) as described above.

Statistical analysis: Statistical analysis of the data was performed with SPSS Statistical software version 16.00 (2001).

\section{RESULTS AND DISCUSSION}

It is evident from table 1 that garlic gave cent per cent inhibition of mycelial growth of all the four isolates $\left(\mathrm{SCC}_{1}, \mathrm{SCC}_{2}, \mathrm{SCC}_{3}\right.$ and $\left.\mathrm{SCC}_{4}\right)$ of $C$. capsici at all concentrations. However, neem showed cent per cent inhibition of mycelial growth of C. capsici at $0.1 \%$. Citronella oil was least effective among the botanical oils. The tested botanical oils caused a significant reduction in growth of $C$. capsici. This reduction was gradually increased by increasing the concentration of extracts in the growth medium. The present finding is in accordance with the findings of Tiwari et al. (2008) reported that plant extracts datura leaf, onion and garlic bulb extracts completely inhibited the growth and sporulation of $C$. capsici. Many researchers have reported the antimicrobial activity of essential oils against different fungal species (Mishra and Dubey, 1994; Tzortzakis, 2007; Viudamartos et al., 2007). The biological activity of essential oils and their components are generally active against a broad spectrum of pest; interspecic toxicity of individual oils and compounds are highly idiosyncratic. Perhaps the most attractive aspect of using essential oils and their constituents in pest management is thei favourable mammalian toxicity and their non-persistence in the environment (Isman, 2000).

Results summarized in table 2 indicates that among the biocontrol agents tested T. harzianum isolate Th-2 was found most effective giving $77.78 \%, 100 \%, 83.33$ $\%$ and $88.89 \%$ inhibition on the mycelial growth of $\mathrm{SCC}_{1}, \mathrm{SCC}_{2}, \mathrm{SCC}_{3}$ and $\mathrm{SCC}_{4}$ respectively followed by T. harzianum isolate Th-1 inhibiting $74.00 \%, \quad 78.9 \%$ $81.7 \%$ and $80.90 \%$ of the mycelial growth of $\mathrm{SCC}_{1}, \mathrm{SCC}_{2}$, $\mathrm{SCC}_{3}$ and $\mathrm{SCC}_{4}$ respectively while $P$. fluorescens was least effective. Ushakiran et al. (2006) observed that in dual culture technique with six biocontrol agents (T. harzianum, T. hamatum, $T$. viride, Verticillium lecanii, Beauberia bassiana and Metarhizium anisopliae) T.harzianum, T. hamatum and T. viride could induce maximum percent inhibition on the linear growth of C. capsici. Bailey et al., (2004) had reported biological control by antagonism as a potential, non-chemical and eco-friendly approach for managing plant diseases. Statistical analysis of the results revealed signicance of the data at $5 \%$ level of significance.

\section{Conclusion}

It was concluded that Garlic, Neem, Trichoderma harzianum and Trichoderma viride can give promising results in controlling the growth of $C$. capsici under laboratory conditions. Recently there has been great interest in essential oils and biocontrol agents for controlling plant pathogens. The present study shows that botanical oils possess antifungal activity and can be exploited for effective management of plant diseases. Potential antagonistic organisms should be screened and formulated for eco-friendly management plant diseases.

\section{REFERENCES}

Ashwini, N. and Srividya, S. (2014). Potential of Bacillus subtilis as biocontrol agent for management of anthracnose disease of chilli caused by Colletotrichum gloeosporioides OGC1. 3 Biotech, 4(2): 127-136.

Bailey, D.J.,Kleczkowski, A. and Gilligan, C.A. (2004). Epidemiological dyanamics and the efficiency of biological control of soil borne disease during consecutive epidemics in a controlled environment. New Phytologist, 161: 569-575.

Faheem, A., Razdan, V.K., Mohiddin, F.A., Bhat, K.A. and Sheikh, P.A. (2010). Effect of volatile metabolites of Trichoderma species against seven fungal plant pathogens in vitro. Journal of Phytology, 2: 34-37.

Isman, M.B. (2000). Plant essential oils for pest and disease management. Crop protection, 19: 603-608.

Mishra, A.K. and Dubey, N.K. (1994). Evaluation of some essential oils for their toxicity against fungi causing deterioration of stored food commodities. Applied Environmental microbiology, 60:1101-1105.

Shervelle, E.G. (1979). Plant disease control. AVI Publishing Company, Inc. West, Post. Connecticut.

SPSS Inc (2001). SPSS Base 11.0 for Windows User's Guide Englewood Cliffs, N J: Prentice Hall.

Than, P.P., Prihastuti, H., Phoulivong, S., Taylor, P.W.J. and Hyde, K.D (2008). Chilli anthracnose disease caused by Colletotrichum species. Journal of Zhejiang University Sciences, 9(10): 764-778.

Tiwari, P.K., Anil, K., Awadhiya, G.K. and Thrimurty, V.S. (2008). Efficacy of bioagents, neem based plant products and plant extracts against Colletotrichum capsici. Indian Journal of Plant Pathology, 36(1) 94-97. 
Tzortzakis, N.G. (2007). Maintaning post harvest quality of fresh produce with volatile compounds. Innovative Food Science Emerging Technology, 8:111-116.

Ushakiran, L.,Chhetry, G.K.N. and Singh, N.I (2006). Fruit rot diseases of chilli and their management in agro-climatic conditions of Manipur. Journal of Mycopathological Research, 44(2): 257-262.

Vincent, J.M. (1947). Distortion of fungal hyphae in presence of certain inhibitors. Nature, 159: 239-241.
Viuda-martos, M., Ruiz-navajas, Y., Fernaadez-lopez, J. and Perez-alvarez, J.A. (2007). Antifungal activities of thyme, clove and organo essential oils. Journal of Food Safety. 27: 91-101.

Voorrips, R.E., Finkers, R., Sanjaya, L. and Groenwold, R. (2004). QTL mapping of anthracnose (Colletotrichum spp.) resistance in a cross between Capsicum annuum and $C$. chinense. Theoretical and Applied Genetics, 109(6):1275-1282. 